\title{
New isocopalane diterpene diester from a sub-Antarctic marine nudibranch
}

\author{
Albert W. W. van Wyk, ${ }^{\text {a }}$ P. William Froneman, ${ }^{b}$ Kim S. Bernard, ${ }^{b}$ and \\ Michael T. Davies-Coleman ${ }^{\mathrm{a} *}$ \\ ${ }^{a}$ Department of Chemistry, Rhodes University, Grahamstown, 6140, South Africa \\ ${ }^{b}$ Southern Ocean Group, Department of Zoology and Entomology, Rhodes University, \\ Grahamstown, 6140, South Africa \\ E-mail: m.davies-coleman@ru.ac.za
}

Dedicated to Professor Berhanu M. Abegaz on his $60^{\text {th }}$ birthday

\begin{abstract}
Two known isocopalane diterpene diacylglycerides $\mathbf{1}$ and $\mathbf{2}$ and one new isocopalane diterpene diacetate, $(12 S, 13 R, 14 S)$-isocopalan-13-ol-12,14-diacetate, 3 were isolated from an unidentified sub-Antarctic nudibranch. The structure and stereochemistry of the new minor metabolite $\mathbf{3}$ was established from spectroscopic data and recourse to biosynthetic arguments.
\end{abstract}

Keywords: Nudibranch, isocopalane diterpene, diacylglyceride

\section{Introduction}

Dorid nudibranchs, or sea slugs, (Order Nudibranchia, Suborder Doridina) are soft-bodied, often brightly coloured, shell-less marine opisthobranch molluscs with surprisingly few predators. ${ }^{1}$ The dorid nudibranch species occurring in the Southern Ocean surrounding Antarctic are no exception and, in common with their warmer water counterparts, are able to defend themselves against predators by exuding unpalatable secondary metabolites from specialized glands strategically located in their mantle tissue., ${ }^{2,3}$ However, while most warmer water nudibranch species sequester their toxic chemical defence metabolites from their diet of other marine invertebrates e.g. sponges and soft corals, the majority of Antarctic species are not restricted to a dietary source for their defensive metabolites and instead biosynthesize these metabolites de novo. ${ }^{2}$ Clerodane, ent-labdane and isocopalane diterpenoid glyceryl esters clearly dominate the structural classes of chemical defence metabolites reported thus far from Antarctic dorid nudibranchs. ${ }^{3,4}$ As part of our ongoing investigation of the secondary metabolites either 
sequestered or biosynthesized de novo by southern African and Antarctic nudibranchs ${ }^{5-8}$ we have extended our studies to include those nudibranchs occurring off Marion Island in the Southern Ocean (approximately $1800 \mathrm{~km}$ south east of South Africa).

\section{Results and Discussion}

A single large yellow nudibranch was dredged from a depth of $115 \mathrm{~m}$ near Marion Island $\left(46^{\circ}\right.$ $52^{\prime} \mathrm{S}, 37^{\circ} 54^{\prime} \mathrm{E}$ ) during early autumn, 2005. The nudibranch was initially frozen, steeped in acetone and the acetone extract concentrated in vacuo to yield a brown gum $(380 \mathrm{mg})$. The brown gum was subjected to initial polymeric reversed-phase separation followed by flash chromatography using a diol solid support and finally normal phase HPLC to yield the two known isocopalane diterpene diacylglycerides $1\left(29 \mathrm{mg},[\alpha]_{\mathrm{D}}{ }^{25}=+10.4\right)$ and $2\left(10 \mathrm{mg},[\alpha]_{\mathrm{D}}{ }^{25}+\right.$ 23.3) and the new isocopalane diterpene diacetate $3\left(3 \mathrm{mg},[\alpha]_{\mathrm{D}}{ }^{25}+3\right)$.

Isomers 1 and $\mathbf{2}$ have been previously reported from two nudibranch species, viz. Anisodoris fontaini (originally erroneously identified as Archidoris carvi) ${ }^{9,10}$ collected off Patagonia (southern Argentina) and Doris verucossa obtained from the Mediterranean. ${ }^{11}$ The closely related diastereoisomers $\mathbf{4}$ and $\mathbf{5}$ were first identified in extracts of the British Columbian nudibranch Archidoris montereyensis ${ }^{12}$ and were also later isolated from the Patagonian nudibranch Archidoris tuberculata. ${ }^{9}$ Comparison of the CD data of $\mathbf{1}$ with analogous data obtained for its stereoisomer $\mathbf{4}$, and the respective oxidation and reduction products of both compounds was originally used to unequivocally confirm that $\mathbf{4}$ was a diastereoisomer of $\mathbf{1}$, possessing an ent-isocopalane as opposed to an isocopalane diterpene skeleton and sharing the same $\left(S-2^{\prime}\right)$ absolute configuration in the glyceryl side chain. ${ }^{9}$ An $(S)$ configuration at the single chiral centre in the glyceryl side-chain is a common feature amongst the plethora of 1,3diacylglycerides isolated thus far from marine molluscs. ${ }^{13}$

Stereoselective syntheses of 1, 2, 4 and $\mathbf{5}$ have clearly confirmed the positive and negative signs of the specific rotation for the isocopalane diacylglyceride and ent-isocopalane diacylglyceride series respectively (Table 1). ${ }^{13,14}$ Fontana et al. ${ }^{14}$ attributed the discrepancy between the magnitude of the specific rotation originally reported for $\mathbf{2}$ isolated from Anisodoris fontaini and the value which they obtained for their synthetic product, to the errors often associated with measuring the optical rotation of diminishing small amounts $(<1 \mathrm{mg})$ of a marine natural product.

The molecular formula of $\mathbf{3}$ was established as $\mathrm{C}_{24} \mathrm{H}_{40} \mathrm{O}_{5}$ from HRFABMS data $\left([\mathrm{M}+\mathrm{H}]^{+}, m / z\right.$ 409.2953, calcd. $m / z$ 409.2954) and implied five degrees of unsaturation for this compound. A comparison of the ${ }^{13} \mathrm{C}$ and ${ }^{1} \mathrm{H} \mathrm{NMR}$ data of $\mathbf{3}$ (Table 2) with those of $\mathbf{1}$ and $\mathbf{2}$ not only suggested that all three compounds shared the same tricyclic isocopalane skeleton but also confined the differences between $\mathbf{3}$ and the former two compounds to the substitution pattern around ring $\mathrm{C}$. These differences were, first, the absence of the deshielded $\Delta^{12}$ olefin resonances in the ${ }^{13} \mathrm{C} N \mathrm{NR}$ spectrum of $\mathbf{3}$ and, second, the absence of any signals in the NMR data of this compound that 
could be attributed to a glyceryl ester moiety. In addition, the combination of the two methyl singlets $\left(\delta_{\mathrm{H}} 1.65\right.$ and 1.72) in the ${ }^{1} \mathrm{H}$ NMR spectrum and two ester carbonyl signals $\left(\delta_{\mathrm{C}} 169.3\right.$ and 169.7) in the ${ }^{13} \mathrm{C}$ NMR spectrum of 3 corroborated the presence of two acetate moieties, thus accounting for the remaining two degrees of unsaturation and four of the five oxygen atoms required by the molecular formula.
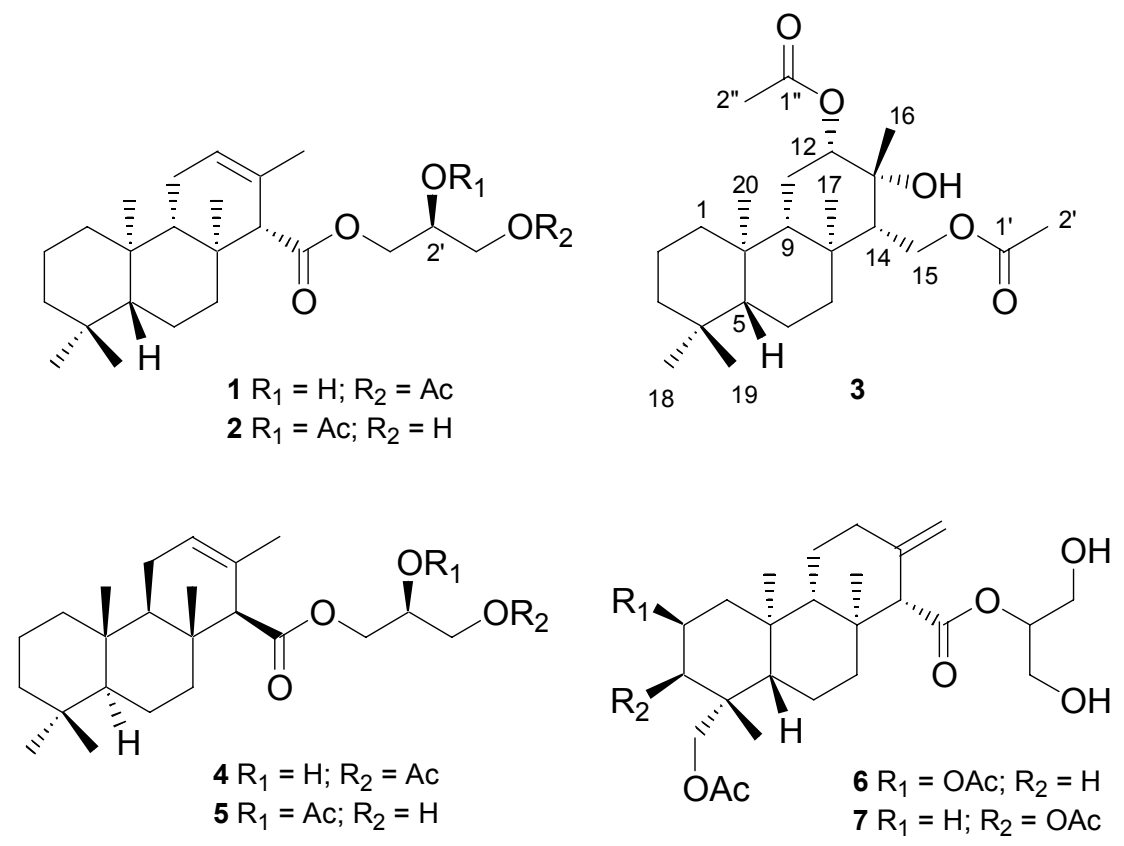

Table 1. Specific rotations reported for naturally occurring and synthetic 1, 2, 4 and 5

\begin{tabular}{cccc}
\hline \multicolumn{3}{c}{ Source } \\
\hline Compound & $\begin{array}{c}\text { Archidoris } \\
\text { monteryensis }\end{array}$ & $\begin{array}{c}\text { Anisodoris } \\
\text { fontaini }\end{array}$ & Synthesis \\
\hline $\mathbf{1}$ & - & $+21.9^{9}$ & $+13.9^{13}$ \\
$\mathbf{2}$ & - & $+66.9^{9}$ & $+10.2^{14}$ \\
$\mathbf{4}$ & $-53.7^{12}$ & - & $-47.7^{13}$ \\
$\mathbf{5}$ & $-33.0^{12}$ & - & $-41.8^{13}$ \\
\hline
\end{tabular}

A vicinal COSY coupling between the diastereotopic, deshielded oxymethylene protons $\left(\delta_{\mathrm{H}}\right.$ 4.25 and 4.27$)$ and the methine proton $\mathrm{H}-14\left(\delta_{\mathrm{H}} 1.44\right)$ placed an esterified oxymethylene sidechain at C-14 $\left(\delta_{\mathrm{C}} 58.0\right)$. Further evidence for this assignment was provided by three bond HMBC correlations from the oxymethylene protons $\mathrm{H}_{2}-15$ to one of the acetate carbonyls $\left(\delta_{\mathrm{C}} 169.7\right)$ in addition to two quaternary carbons, $\mathrm{C}-8$ and $\mathrm{C}-13$ ( $\delta_{\mathrm{C}} 13.7$ and 74.6 respectively). Confirmation that both $\mathrm{C}-12$ and $\mathrm{C}-13$ were oxygenated was provided by the ${ }^{13} \mathrm{C}$ chemical shift of the deshielded $\mathrm{C}-13$ resonance and a two bond $\mathrm{HMBC}$ correlation from the methyl protons $\left(\delta_{\mathrm{H}} 1.12\right.$, $\left.\mathrm{H}_{3}-16\right)$ to the similarly deshielded $\mathrm{C}-12$ methine carbon $\left(\delta_{\mathrm{C}} 78.3\right)$. An HMBC correlation from 
$\mathrm{H}-12\left(\delta_{\mathrm{H}} 5.01\right)$ to the ester carbonyl C-1" $\left(\delta_{\mathrm{C}} 169.3\right)$ placed the second acetate at C-12 and thus required the remaining oxygen substituent at $\mathrm{C}-13$ to be a tertiary alcohol.

Table 2. ${ }^{1} \mathrm{H}(600 \mathrm{MHz})$ and ${ }^{13} \mathrm{C}(150 \mathrm{MHz}) \mathrm{NMR}$ data $\left(\mathrm{C}_{6} \mathrm{D}_{6}\right)$ for 3

\begin{tabular}{|c|c|c|c|c|c|}
\hline Position & $\delta_{\mathrm{C}}($ mult $)$ & $\delta_{\mathrm{H}}$ & Mult. $(J)$, int & HMBC correlation to & $\begin{array}{c}\text { COSY coupling } \\
\text { to }\end{array}$ \\
\hline \multirow[t]{2}{*}{1} & $40.5(\mathrm{t})$ & 0.69 & $\mathrm{~m}, 1 \mathrm{H}$ & 20 & $1 \mathrm{~b}, 2$ \\
\hline & & 1.57 & $\mathrm{~m}, 1 \mathrm{H}$ & & $1 \mathrm{a}, 2$ \\
\hline 2 & $18.9(\mathrm{t})^{*}$ & 1.32 & $\mathrm{~m}, 2 \mathrm{H}$ & - & $1 \mathrm{a}, 1 \mathrm{~b}, 3 \mathrm{a}$ \\
\hline \multirow[t]{2}{*}{3} & $42.3(\mathrm{t})$ & 1.09 & $\mathrm{~m}, 1 \mathrm{H}$ & 2,4 & $2,3 b, 18$ or 19 \\
\hline & & 1.34 & $\mathrm{~m}, 1 \mathrm{H}$ & & $3 a$ \\
\hline 4 & $33.5(\mathrm{~s})$ & & - & - & - \\
\hline 5 & $57.2(\mathrm{~d})$ & 0.73 & $\mathrm{dd}(12.0,2.2), 1 \mathrm{H}$ & $6,7,9,10,20,18,19$ & $6 a, 6 b$ \\
\hline \multirow[t]{2}{*}{6} & $18.7(\mathrm{t})^{*}$ & 1.48 & $\mathrm{~m}, 1 \mathrm{H}$ & $8,7,10,17$ & $5,7 \mathrm{a}, 7 \mathrm{~b}$ \\
\hline & & 1.50 & $\mathrm{~m}, 1 \mathrm{H}$ & & $5,7 \mathrm{a}, 7 \mathrm{~b}$ \\
\hline \multirow[t]{2}{*}{7} & $39.1(\mathrm{t})$ & 1.30 & $\mathrm{~m}, 1 \mathrm{H}$ & 17 & 6 \\
\hline & & 1.53 & $\mathrm{~m}, 1 \mathrm{H}$ & - & 6 \\
\hline 8 & $38.7(\mathrm{~s})$ & & - & - & - \\
\hline 9 & $52.6(\mathrm{~d})$ & 1.35 & $\mathrm{~m}, 1 \mathrm{H}$ & $8,10,11,12,20,17$ & 11 \\
\hline 10 & $38.0(\mathrm{~s})$ & & - & - & - \\
\hline \multirow[t]{2}{*}{11} & $23.7(t)$ & 1.76 & $\mathrm{~m}, 1 \mathrm{H}$ & $8,9,12,13,14,2 "$ & 9,12 \\
\hline & & 1.80 & $\mathrm{~m}, 1 \mathrm{H}$ & & 9,12 \\
\hline 12 & $78.3(\mathrm{~d})$ & 5.01 & $\mathrm{dd}(11.2,5.0), 1 \mathrm{H}$ & $11,1^{\prime \prime}$ & $11 \mathrm{a}, 11 \mathrm{~b}$ \\
\hline 13 & $74.6(\mathrm{~s})$ & - & - & - & - \\
\hline 14 & $58.0(\mathrm{~d})$ & 1.44 & $\mathrm{~m}, 1 \mathrm{H}$ & $8,9,12,13,15,20$ & $15 a, 15 b$ \\
\hline \multirow[t]{2}{*}{15} & $62.8(\mathrm{t})$ & 4.15 & $\mathrm{dd}(12.8,3.8), 1 \mathrm{H}$ & $8,13,14,1^{\prime}$ & 14 \\
\hline & & 4.27 & $\mathrm{dd}(12.8,2.5), 1 \mathrm{H}$ & $8,13,14,1^{\prime}$ & 14 \\
\hline 16 & $27.2(\mathrm{q})$ & 1.12 & $\mathrm{~s}, 3 \mathrm{H}$ & $12,13,14$ & - \\
\hline 17 & $26.1(q)$ & 1.41 & $\mathrm{~s}, 3 \mathrm{H}$ & $8,9,14$ & \\
\hline 18 & $21.7(\mathrm{q})$ & 0.80 & $\mathrm{~s}, 3 \mathrm{H}$ & $3,4,5,19$ & - \\
\hline 19 & $33.6(q)$ & 0.83 & $\mathrm{~s}, 3 \mathrm{H}$ & $3,4,5,18$ & - \\
\hline 20 & $16.6(q)$ & 0.82 & $\mathrm{~s}, 3 \mathrm{H}$ & $1,9,10$ & - \\
\hline $1^{\prime}$ & $169.7(\mathrm{~s})$ & - & - & - & - \\
\hline $2^{\prime}$ & $20.6(q)$ & 1.72 & $\mathrm{~s}, 3 \mathrm{H}$ & $1^{\prime}$ & - \\
\hline $1 "$ & $169.3(\mathrm{~s})$ & - & - & - & - \\
\hline $2 "$ & $20.6(q)$ & 1.65 & $\mathrm{~s}, 3 \mathrm{H}$ & $1 "$ & - \\
\hline
\end{tabular}

* Signals may be interchangeable 
The relative configurations at $\mathrm{C}-12, \mathrm{C}-13$ and $\mathrm{C}-14$ were determined from NOESY data (Figure 1). Crucial NOESY correlations between $\mathrm{H}-9\left(\delta_{\mathrm{H}} 1.35\right)$ and $\mathrm{H}-12\left(\delta_{\mathrm{H}} 5.01\right)$ and between $\mathrm{H}-12$ and $\mathrm{H}-14\left(\delta_{\mathrm{H}} 1.44\right)$ implied a $c i s$ relationship between these three axial methine protons and accordingly placed the substituents at $\mathrm{C}-12$ and $\mathrm{C}-14$ in $\alpha$-equatorial positions. A further NOESY correlation between $\mathrm{H}-12$ and $\mathrm{H}_{3}-16(\delta$ 1.12) required the methyl and hydroxyl substituents at $\mathrm{C}-13$ to be $\beta$-equatorial and $\alpha$-axial respectively. The co-occurrence of $\mathbf{1}, \mathbf{2}$ and $\mathbf{3}$ in the Marion Island nudibranch suggests that all three compounds are products of a similar biosynthetic pathway and hence share the same isocopalane diterpene structure.

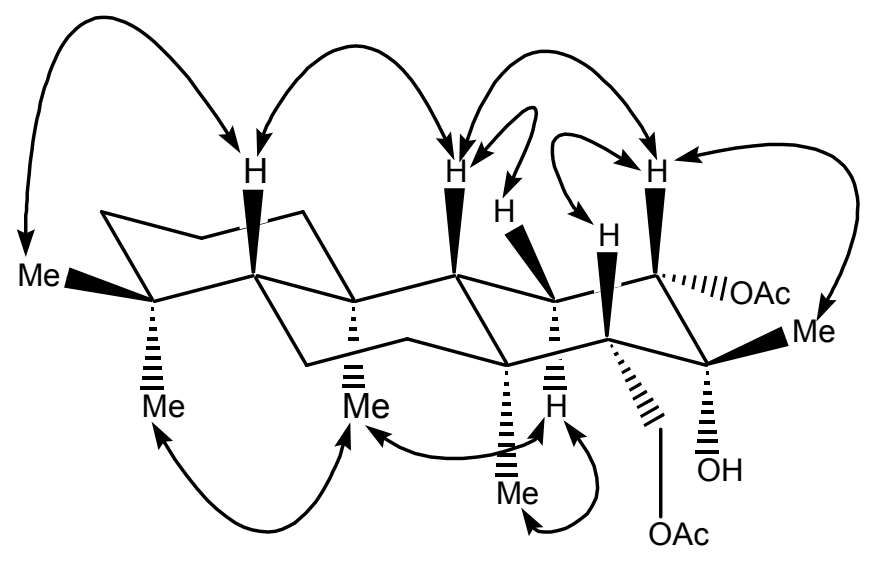

Figure 1. Key NOESY correlations observed in the NOESY spectrum of $\mathbf{3}$.

Regrettably, the acetone solvent dehydrated and distorted the Marion Island nudibranch's radula (a chitinous ribbon of teeth used by most molluscs for feeding and by mollusc taxonomists for identification purposes) to such an extent that the nudibranch could not be positively identified. A tentative identification of the Marion Island nudibranch based on chemotaxonomic evidence was also inconclusive as isocopalane diterpenes are not confined to the genera Doris and Anisodoris. For example isocopalane 2'-monoglyceryl esters austrodorins A (6) and B (7) were isolated from Austrodoris kerguelenensis, ${ }^{15}$ a large and ubiquitous Antarctic and sub-Antarctic nudibranch ranging in colour from white to yellow and a rich source of a wide variety of diterpene metabolites. ${ }^{4}$ The Kerguelen Islands whence $A$. kerguelenensis derives its name, are situated $800 \mathrm{~km}$ due east of Marion Island.

\section{Conclusions}

A new isocopalane diterpene diacetate, $(12 S, 13 R, 14 S)$-isocopalan-13-ol-12,14-diacetate, has been isolated from a single dorid nudibranch dredged from $115 \mathrm{~m}$ near Marion Island in the Southern Ocean. The stereochemistry assigned to this compound was implied from recourse to biosynthetic arguments. The research presented here represents the first investigation of the 
natural products isolated from a marine invertebrate collected off this remote sub-Antarctic island and identifies a new source of naturally occurring isocopalanes, a class of rare and apparently uniquely marine diterpenes. ${ }^{16}$

\section{Experimental Section}

General Procedures. NMR spectra were measured on a Brüker $600 \mathrm{MHz}$ NMR spectrometer using standard pulse sequences. Chemical shifts are reported in ppm and are referenced to residual solvent resonances $\left(\mathrm{C}_{6} \mathrm{D}_{6} \delta_{\mathrm{H}} 7.15, \delta_{\mathrm{C}}\right.$ 128.02). ${ }^{17}$ HRFABMS data were obtained on a JEOL SX102 FAB mass spectrometer. Diaion HP-20 polystyrene divinylbenzene beads (supplied by Supelco) and Macherey-Nagel Chroma-Bond $\mathrm{OH}$ Diol $(0.45 \mu \mathrm{m})$ were used for initial chromatographic separations. High-performance liquid chromatography was performed using a Whatman's Magnum 9, Partisil 10 semi-preparative column.

Extraction and isolation. The single yellow nudibranch specimen $(6 \times 8 \mathrm{~cm})$ was dredged from a depth of $115 \mathrm{~m}$ near Marion Island $\left(46^{\circ} 52^{\prime} \mathrm{S}, 37^{\circ} 54^{\prime} \mathrm{E}\right)$ during early autumn, 2005, photographed (Figure 2), immediately frozen and kept at $-20{ }^{\circ} \mathrm{C}$ until it could be transferred to $\mathrm{Me}_{2} \mathrm{CO}(250 \mathrm{~mL})$.

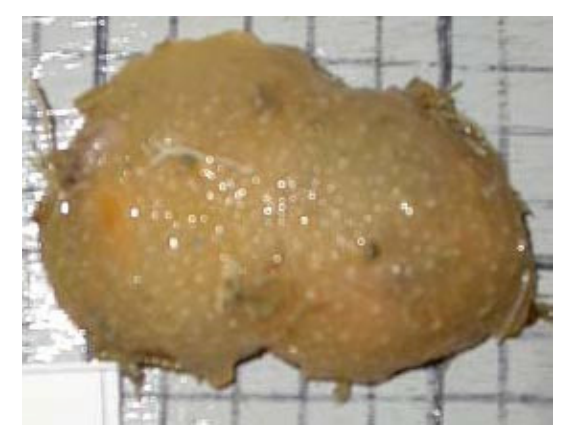

Figure 2. Photograph of nudibranch shortly after collection.

The nudibranch was exhaustively extracted with $\mathrm{Me}_{2} \mathrm{CO}$, the extracts combined and the solvent removed under reduced pressure. The combined acetone extract was loaded onto an HP-20 column $(1.25 \times 10 \mathrm{~cm}, 50 \mathrm{~mL})$ and eluted with aliquots $(150 \mathrm{~mL})$ of increasing concentration of $\mathrm{Me}_{2} \mathrm{CO}$ in $\mathrm{H}_{2} \mathrm{O}\left(0,20 \%, 40 \%, 60 \%, 80 \%\right.$ and $\left.100 \% \mathrm{Me}_{2} \mathrm{CO}\right)$. The $80 \% \mathrm{Me}_{2} \mathrm{CO}_{(\mathrm{aq})}$ eluent was concentrated in vacuo (194 mg), re-dissolved in $\mathrm{MeOH}(\mathrm{ca} .5 \mathrm{~mL})$ and evaporated onto a small portion of diol stationary phase $(1 \mathrm{~mL})$. The diol onto which the organic material had been absorbed was transferred as a hexane slurry onto a flash-column of diol (1 x $11 \mathrm{~cm}, 9 \mathrm{~mL})$ which was eluted with aliquots $(100 \mathrm{~mL})$ of (i) EtOAc/95\% hexane, (ii) EtOAc/90\% hexane, (iii) EtOAc $/ 75 \%$ hexane, (iv) EtOAc/50\% hexane (v) EtOAc, (vi) 50\% MeOH/50\% EtOAc, (vii) 
MeOH. ${ }^{1} \mathrm{H}$ NMR analysis of the diol chromatography fractions identified diterpene metabolites in fractions (i) and (ii). Further purification of fraction (ii) $(50.5 \mathrm{mg})$ by normal phase HPLC (EtOAc/65\% hexane) yielded 1 (19.1 mg) and 2 (9.5 mg) while normal phase HPLC (EtOAc/65\% hexane) of fraction (i) $(80.5 \mathrm{mg})$ yielded $1(10.1 \mathrm{mg})$ and $\mathbf{3}(2.7 \mathrm{mg})$.

Compound 1. Yellow oil: $[\alpha]_{\mathrm{D}}{ }^{25}=+10.4\left(c=2.0, \mathrm{CHCl}_{3}\right), \mathrm{lit}^{9,13}+13.9,+21.9 .{ }^{1} \mathrm{H}$ and ${ }^{13} \mathrm{C} \mathrm{NMR}$ data consistent with published values, ${ }^{9,12}$ HRFABMS obsd. $(\mathrm{M}+\mathrm{H})^{+} m / z$ 421.2954, $\mathrm{C}_{25} \mathrm{H}_{41} \mathrm{O}_{5}$ requires $m / z 421.2954$.

Compound 2. Yellow oil: $[\alpha]_{\mathrm{D}}{ }^{25}+23.3\left(c=1.0, \mathrm{CHCl}_{3}\right)$, lit ${ }^{9,14}+10.2,+66.9 .{ }^{1} \mathrm{H}$ and ${ }^{13} \mathrm{C} \mathrm{NMR}$ data consistent with published values, ${ }^{9,12}$ HRFABMS obsd. $[\mathrm{M}+\mathrm{H}]^{+} m / z$ 421.2956, $\mathrm{C}_{25} \mathrm{H}_{41} \mathrm{O}_{5}$ requires $m / z 421.2954$.

(12S, 13R, 14S)-Isocopalan-13-ol-12,14-diacetate (3). Yellow oil: $[\alpha]_{\mathrm{D}}{ }^{25}+3.3\left(c=0.2, \mathrm{CHCl}_{3}\right)$; ${ }^{1} \mathrm{H}$ and ${ }^{13} \mathrm{C}$ NMR data see Table 2; HRFABMS obsd. [M+H] ${ }^{+} m / z 409.2953, \mathrm{C}_{24} \mathrm{H}_{41} \mathrm{O}_{5}$ requires $m / z 409.2954$

\section{Acknowledgements}

Research funding from the South African Department of Environmental Affairs and Tourism and the National Research Foundation together with the logistical and research support provided by the captain and crew of the SA Agulhas are gratefully acknowledged.

\section{References}

1. Cimino, G.; Fontana, A.; Gavagnin, M. Curr. Org. Chem. 1999, 3, 327.

2. Iken, K.; Avila, C.; Fontana, A.; Gavagnin, M. Mar. Biol. 2002, 141, 101.

3. Gavagnin, M.; Fontana, A.; Ciavatta, M. L.; Cimino, G. Ital. J. Zool. 2000, 67 (Supp.1), 101.

4. Davies-Coleman, M. T. In Progress in Molecular and Subcellular Biology (Molluscs. From Chemo-ecological Study to Biotechnological Application); Cimino, G.; Gavagnin, M. Eds.; Springer, 2006; Vol. 43, p 133.

5. McPhail, K. L.; Davies-Coleman, M. T.; Starmer, J. J. Nat. Prod. 2001, 64, 1183.

6. McPhail, K.; Davies-Coleman, M.T.; Coetzee, P. J. Nat. Prod. 1998, 61, 961.

7. Davies-Coleman, M. T.; Faulkner, D. J. Tetrahedron 1991, 47, 9743.

8. McClintock, J. B.; Baker, B. J.; Slattery, M.; Heine, J. N.; Bryan, P. J.; Yoshida, W.; DaviesColeman, M. T.; Faulkner, D. J. J. Chem. Ecol. 1994, 20, 3361.

9. Zubia, E.; Gavagnin, M.; Martinez, E.; Ortea, J. and Cimino, C., Ezperientia, 1993, 49, 268.

10. Gavagnin, M.; Ungur, N.; Castelluccio, F.; Muniain, C.; Cimino, G. J. Nat. Prod. 1999, 62, 269.

11. Gavagnin, M.; Ungur, N.; Castelluccio, F.; Cimino, G. Tetrahedron 1997, 53, 1491. 
12. Gustafson, K.; Andersen, R.J. Tetrahedron 1985, 41, 1101.

13. Ungur, N.; Gavagnin, M.; Fontana, A., Cimino, G. Tetrahedron 2000, 56, 2503.

14. Fontana, A.; Ungur, N.; Gavagnin, M.; Salierno, C.; Cimino, C. Tetrahedron Lett. 1997, 23, 4145.

15. Gavagnin, M.; De Napoli, A.; Castelluccio, F.; Cimino, G. Tetrahedron Lett. 1999, 40, 8471.

16. Fattorusso, E.; Romano, A.; Taglialatela-Scafati, O.; Bavestrello, G.; Bonelli, P.; Calcinai, B. Tetrahedron Lett. 2006, 47, 2197.

17. Gottlieb, H. E.; Kotlyar, V.; Nudelman, A. J. Org. Chem. 1997, 62, 7512. 